\title{
Correction: Čapek, P., et al. Sensing the Deadliest Toxin: Technologies for Botulinum Neurotoxin Detection. Toxins 2010, 2, 24-53
}

\section{Petr $\check{C ̆ a p e k}^{1}$ and Tobin J. Dickerson ${ }^{2, *}$}

1 Department of Chemistry, The Scripps Research Institute, 10550 North Torrey Pines Road, La Jolla, CA 92037, USA; E-Mail: capek@ scripps.edu

2 Department of Chemistry and Worm Institute for Research and Medicine, The Scripps Research Institute, 10550 North Torrey Pines Road, La Jolla, CA 92037, USA

* Author to whom correspondence should be addressed; E-Mail: tobin@scripps.edu;

Tel.: +1-858-784-2522; Fax: +1-858-784-2590.

Received: 19 January 2010 / Published: 19 January 2010

We realized that in our paper published recently in Toxins [1] limits of detection (LOD) of multiplexed fluorescent magnetic suspension assay [2] were incorrectly reported to be in the $\mathrm{ng} / \mathrm{mL}$ range. Indeed, LODs of this assay are in the $\mathrm{pg} / \mathrm{mL}$ range and the fourth and fifth sentence in Flow Cytometric Assay section (page 32) should read as follows:

BoNT/A and B were detected at concentrations of $21 \mathrm{pg} / \mathrm{mL}$ and $73 \mathrm{pg} / \mathrm{mL}$, respectively, in 5-plex assay together with ricin, SEB and abrin. This sensitivity was comparable to the sensitivity of an ELISA performed for one analyte at the time with the same set of antibodies (detection limits of $12 \mathrm{pg} / \mathrm{mL}$ and $124 \mathrm{pg} / \mathrm{mL}$, respectively, for BoNT/A and B).

\section{References}

1. Čapek, P.; Dickerson, T.J. Sensing the Deadliest Toxin: Technologies for Botulinum Neurotoxin Detection. Toxins 2010, 2, 24-53.

2. Pauly, D.; Kirchner, S.; Stoermann, B.; Schreiber, T.; Kaulfuss, S.; Schade, R.; Zbinden, R.; Avondet, M.A.; Dorner, M.B.; Dorner, B.G. Simultaneous quantification of five bacterial and 
plant toxins from complex matrices using a multiplexed fluorescent magnetic suspension assay. Analyst 2009, 134, 2028-2039.

(C) 2010 by the authors; licensee Molecular Diversity Preservation International, Basel, Switzerland. This article is an open-access article distributed under the terms and conditions of the Creative Commons Attribution license (http://creativecommons.org/licenses/by/3.0/). 